\title{
The Influence of Social Communication during Covid-19 Pandemic
}

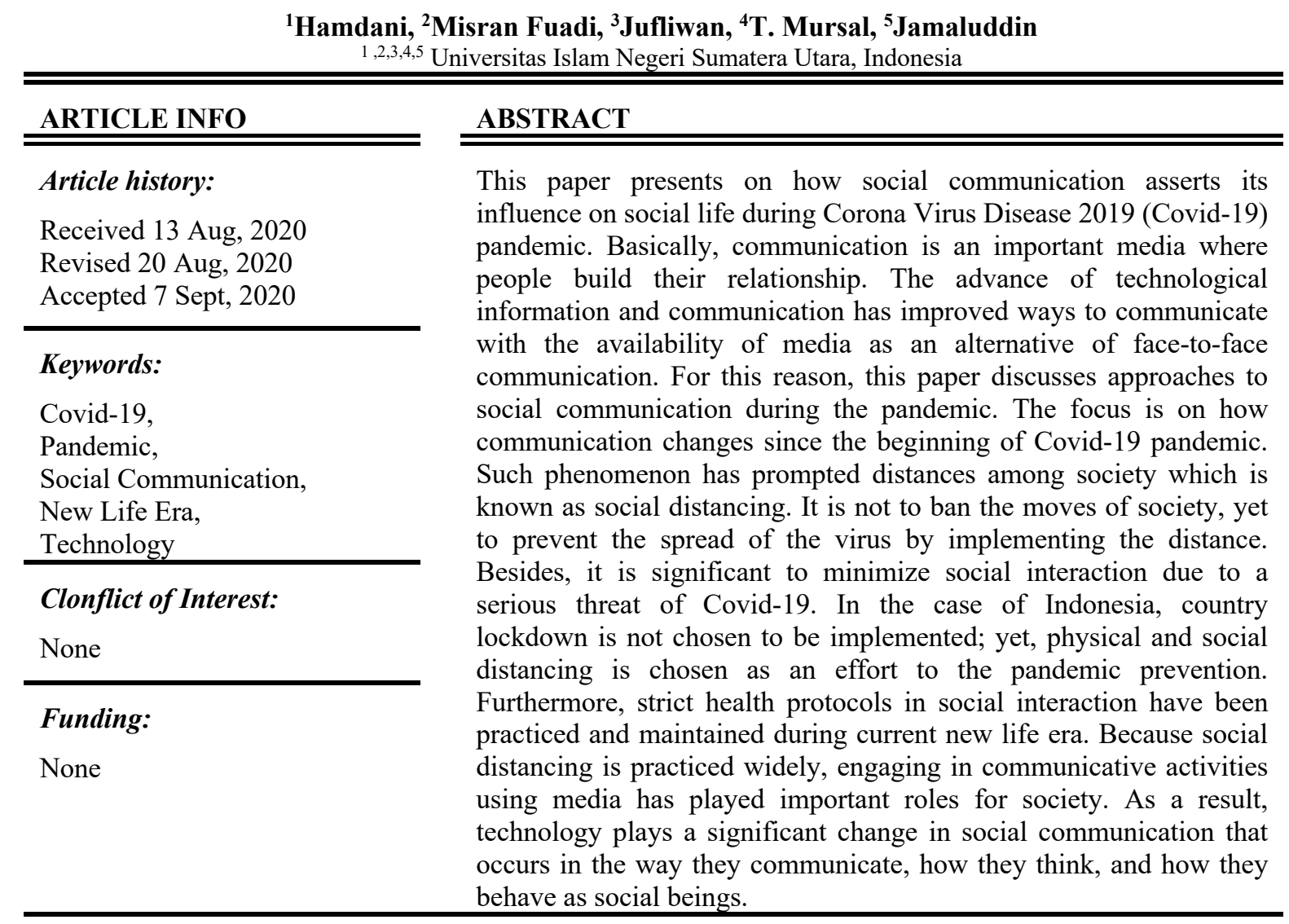

Corresponding Author: Hamdani, S.Pd., M.Pd., UIN Sumatera Utara, Jalan IAIN No.1 Medan, Indonesia. Tel. +62-853-5823-3863. E-mail: hamdanismansa@gmail.com.

(C) Hamdani, Misran Fuadi, Jufliwan, T. Mursal, Jamaluddin

This is an open access article under the CC BY-SA 4.0 international license.

\section{Introduction}

\subsection{Social Problem Problem}

Communication is a medium to build a relationship between human beings. It will create social relationship between a person and another, or to create an interaction with each other. Communicative activities include a wide spectrum. It is an important site to convey someone's problem such as thinking, feeling, and an opinion towards others. In managerial perspective, communication is an integral part of management tool to achieve the aim. In other words, it is a key that can influence people in their social life.

As we know, communication is a vital tool for human beings to understand themselves, others, surrounding as well as social culture. It also gives them a place and an existence in society with who they build a relationship. This only can be achieved with a good medium of communication. Furthermore, communication is not only known in public relations or press, but it also has comprehensive understanding. Either with conscious or unconscious, people has built good communication in all parts of their life.

In social life, communication highly determines values of education, morals and materials. It is a basic human activity wherever they are. People can interact with each other in their domestic life, workplace, 
market, society and etc. For that reason, they cannot avoid communication at all. It is a process where people want to give an understanding with each other through symbolic news.

Human as social creature cannot live without any communication in a way to fulfill their needs. Likewise, globalization era improves fast communication in all aspects of life including politics, economics, social culture and education. Changes and developments of one aspect will influence the other aspect.

\subsection{Approaches of Communication during Covid-19 Pandemic}

At the moment, the biggest dilemma faced by society both local and international world is the issue of widespread Corona Virus Disease 19, known as Covid-19. This dilemma has influenced the changes of social communication in society.

It is caused by the advance of the development on technology and information. People could easily access social issues through media. For that reason, people should be familiar and able to adapt technological advances in their life.

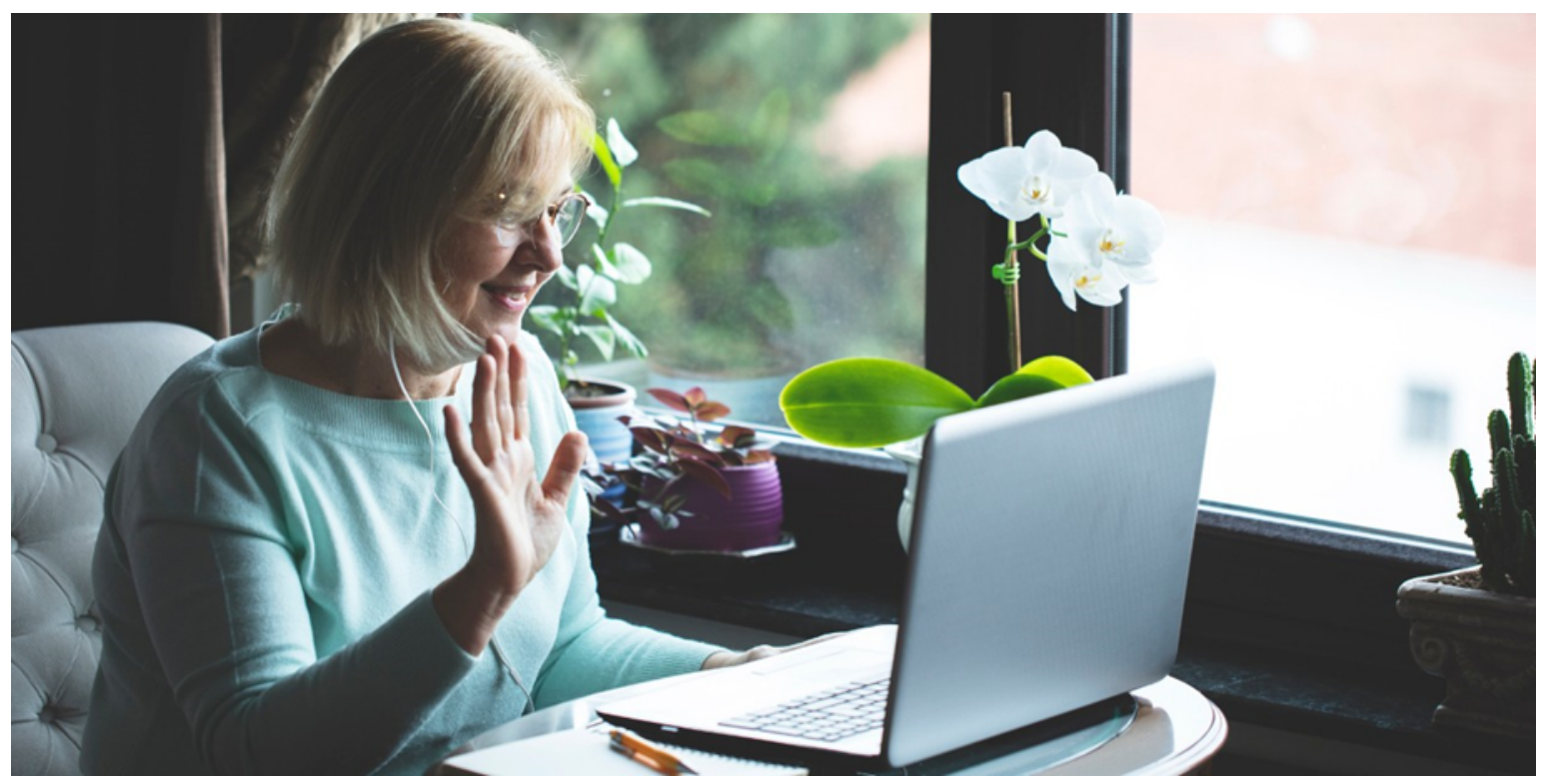

(Source: https://www.folio.ca/new-research-aims-to-find-out-how-different-ways-of-communicating-duringpandemic-affect-our-health-and-well-being/)

Due to Covid-19 pandemic, there are changes in society in terms of ways of communication, thought, and behavior. Basically, social changes in communication are in relation with the development of technology, information and communication through digital media. We unconsciously have practiced those changes in our life.

In his book, Theories of Human Communication, Stephen W. Littlejohn (Sendjaja, 2014) said that there are three approaches in communication between human. The first is scientific approach or known as empirical approach. This approach is widely popular among scientists. Its point of view emphasizes on objectivity and separation between objects being researched and the researcher.

The second is humanistic approach or known as humanistic interpretative. It associates with the principle of subjectivity. People can observe other's attitude and behavior around them so that they can socialize and involve actively in someone's life within their surroundings.

Then, the third is social science approach. This approach is a combination between scientific and humanistic where the object being researched is human including their characters and behaviors. Here, the influence of Covid-19 requires human to participate directly and actively in society. However, the relationship between people is not what as expected.

\section{Results and Discussion}




\subsection{Social Distance within the Interaction of Social Communication}

During Covid-19 pandemic, people those who live in cities or villages need to keep their distance within their surroundings. The procedures of social distancing need to be implemented by the society due to their activities outdoor. The objective of this implementation is to prevent the spread of Covid-19 itself.

Social distance is an effective program to be practiced by all layers of society. This program is not to ban the moves of society. Moreover, such situation is not common for people whose life is currently restricted due to the pandemic. In fact, communication through digital devices has great contribution on social interactions at the moment.

People are able to communicate with others in their social life using various media globally. The advance of technological information and communication either digital or non-digital media should be embraced and practiced in order to maintain social interaction among society. These media can be used in social communication without any obstacles during Covid-19 pandemic. They can be used as learning, marketing and interacting tools among society.

These media can become a bridge in providing information that is educative, informative and persuasive. With media platforms such as Whatsapp, Facebook, Instagram, Twitter and etc, people do not have to be physical in touch with other people in making social interaction both individual and in a group. In this globalization era, such phenomena become a lifestyle for society either for Indonesians locally or international people globally. For instance, people check messages in their smartphone right after they wake up in the morning.

Social media platforms have also become helpful for the lay public to maintain communication with friends and family to reduce isolation and boredom which have been associated with anxiety and long-term distress, therefore becoming an important recommendation for isolation at home to help to reduce the psychological impact.

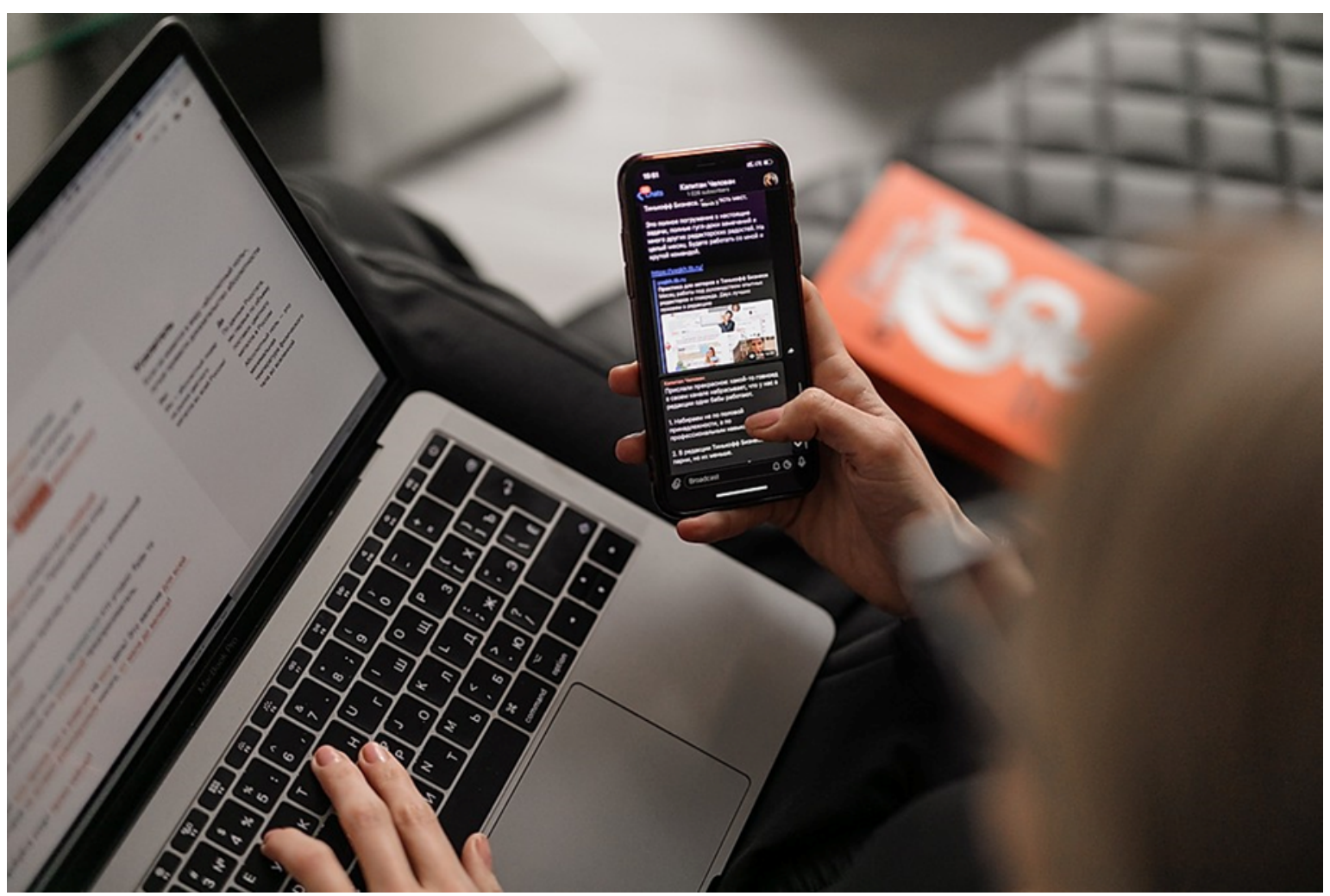

(Source: https://www.digitalartsforall.com/post/how-to-spot-fake-news-and-stop-the-spread-of-it-duringcovid-19-pandemic) 
communication. People do social communication physically or known as face-to-face communicators, or as an informant and a communicant. For that reason, people interact socially using technological information and communication especially with the variety of media that have existed among them.

We are actually concerned with younger generation who has their own world and private interaction among them. Most of them cannot practice social distancing during the pandemic. As a result, majority of society assume that the government policy on social distancing regulation is a big mistake.

With the advance of technological information and communication nowadays, people can interact with each other without having physical presence. As cited from CTV news channel, Dr Maria Van Kerkhove, a head of WHO Task Force for Covid-19, mention about the fight for Corona virus through social distancing. It is an obligation for everyone to make a distance in a public area such as schools, government and non-government offices. Such practice is to discontinue the chain of Covid-19 pandemic. That is why the regulation of social distancing should be implemented for larger scale of society to prevent the spread of the virus.

The appeal for social distancing to be implemented in fighting the spread of Corona virus disease 19 is an instruction from World Health Organization (WHO). It is because the Covid-19 can be easily contagious or infectious through droplets spread by someone when he or she coughs or sneezes. As a result, according to the guideline for the quick handling of medical and public health in Indonesia, social distancing is the restriction of certain activities in a certain area. This applies to everyone who lives in an infected area of Covid-19.

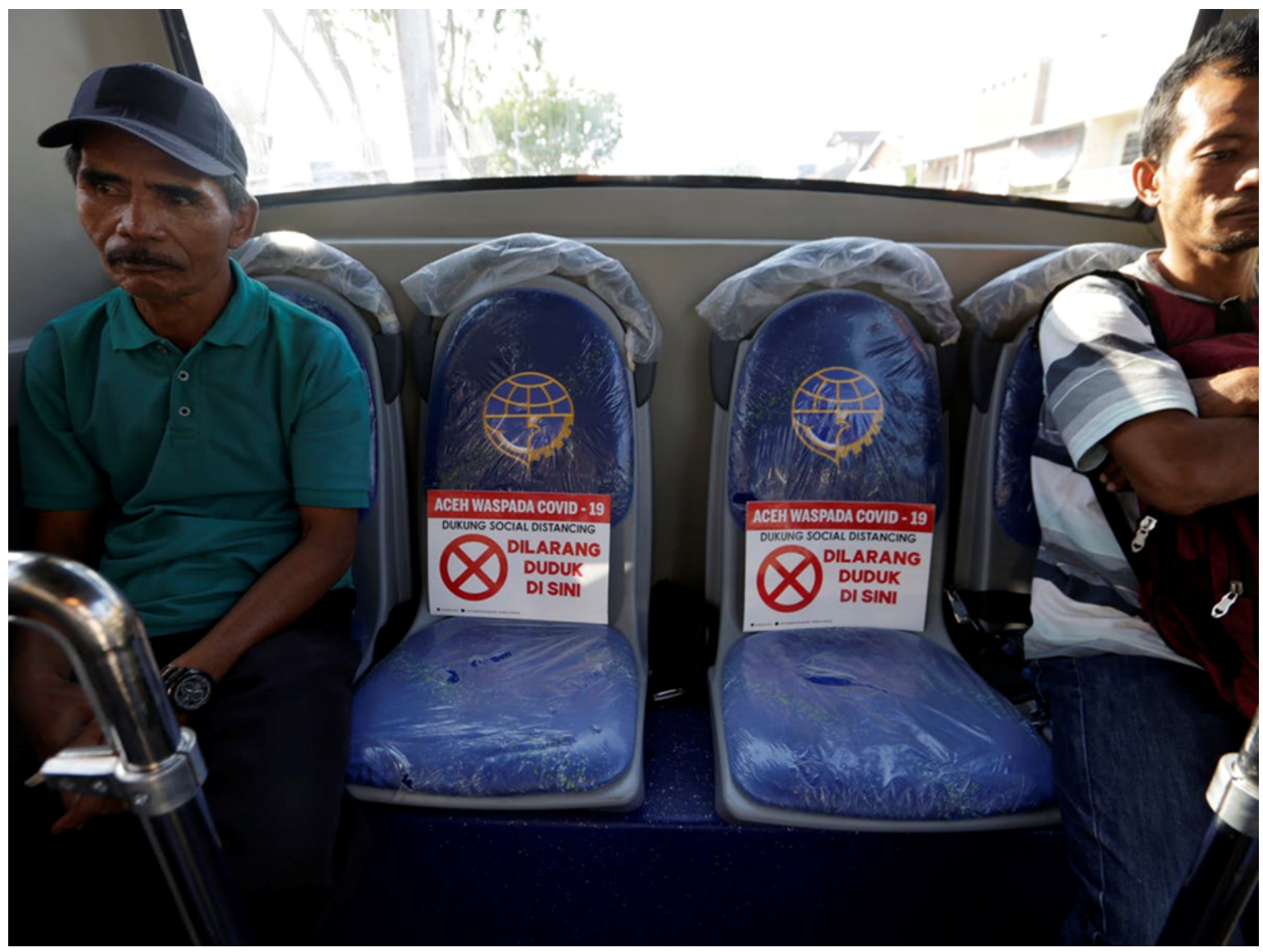

(Source: https://theconversation.com/penerapan-social-distancing-setengah-hati-di-indonesia-berpotensigagal-kurangi-kasus-baru-covid-19-134237) 
The spread of corona virus is serious threat for people all over the world. The more people get infected by the virus, the larger social distancing is required for society to restrict their social interaction during the pandemic.

Minimizing social interaction through social distancing is aimed at preventing the wider spread of corona virus. People should restrict themselves from using public facility and maintain social distancing. It is also important that people should stay at home and do their activities from home. For example, students can study from home and their parents can work from home (WFH) as well. Every family should minimize their visit to public places in order to stop the chain of the virus. Then, people should not be worried too much as what social distancing means in this context is to emphasize on physical distancing. Direct physical in touch without any distance could give a chance for the spread of the virus.

Unfortunately, we do not really understand what social distancing in public place is. That is why we lose our roles as social creature that can interact with each other. At the end, it is only human's thought that turns out becoming a culture.

Therefore, it is hoped that we should not be worried with the changes happening in social life nowadays. It is the demand of current condition worldwide. Even though people's interaction is limited and restricted at the moment, their interaction is always unlimited. In fact, effective communication is done physically within the same place.

\subsection{The Implementation of Distancing in Indonesia during the pandemic}

In overcoming all social problems in people's lives, the Government has issued a certain regulation and requires the hard work of all parties to oversee its application in the midst of community life. Indonesia did not make efforts by lockdown, but made efforts to implement physical and social distancing as a community effort to maintain physical distance and direct communication between people and others during their interaction in order to avoid transmission of Covid-19. Preventing is certainly an impact on the model of relationships or communication between communities that so far have been built and developed.

A habit in the life of the people who have always prioritized togetherness in social life, but for the time being must be avoided with the aim of preventing the spread of the virus. This tradition often occurs in the form of majlis taklim gatherings, bridal receptions, aqiqah, marriage parties and ceremonies of death. The tradition has certain rules that cannot be avoided by someone from a habit of shaking hands, embracing as a symbol of intimacy, and so on. Conducting wedding party or marriage contract must be in strict protocols. Likewise, students either school or university have to take distance learning class. All seminars, workshops and trainings are held online. Even more, the obligation of Friday prayer (controversy) also disappears in some mosques. Finally the term was born to stay at home, work at home, study at home, even worship also at home. If you have to go out, you must wear a mask to cover your mouth so that communication in social life is very influential, as social interaction usually occurs face to face in every institution, both government and non-government institutions.

In a new life era, model in preventing the spread of Covid-19 must be applied with adaptation in a short time. Social interaction is built with physical distance using technological tools such as communication media that have been developed. In addition, there must be safeguards in every village that must be sprayed with disinfectants. Definitely, not all prevention above can be in accordance with new life culture. Some people refuse, and the rest accept it by force. This new lifestyle must inevitably be implemented to prevent the spread of the virus so that the influence of social communication in people's lives quickly ends. 
88

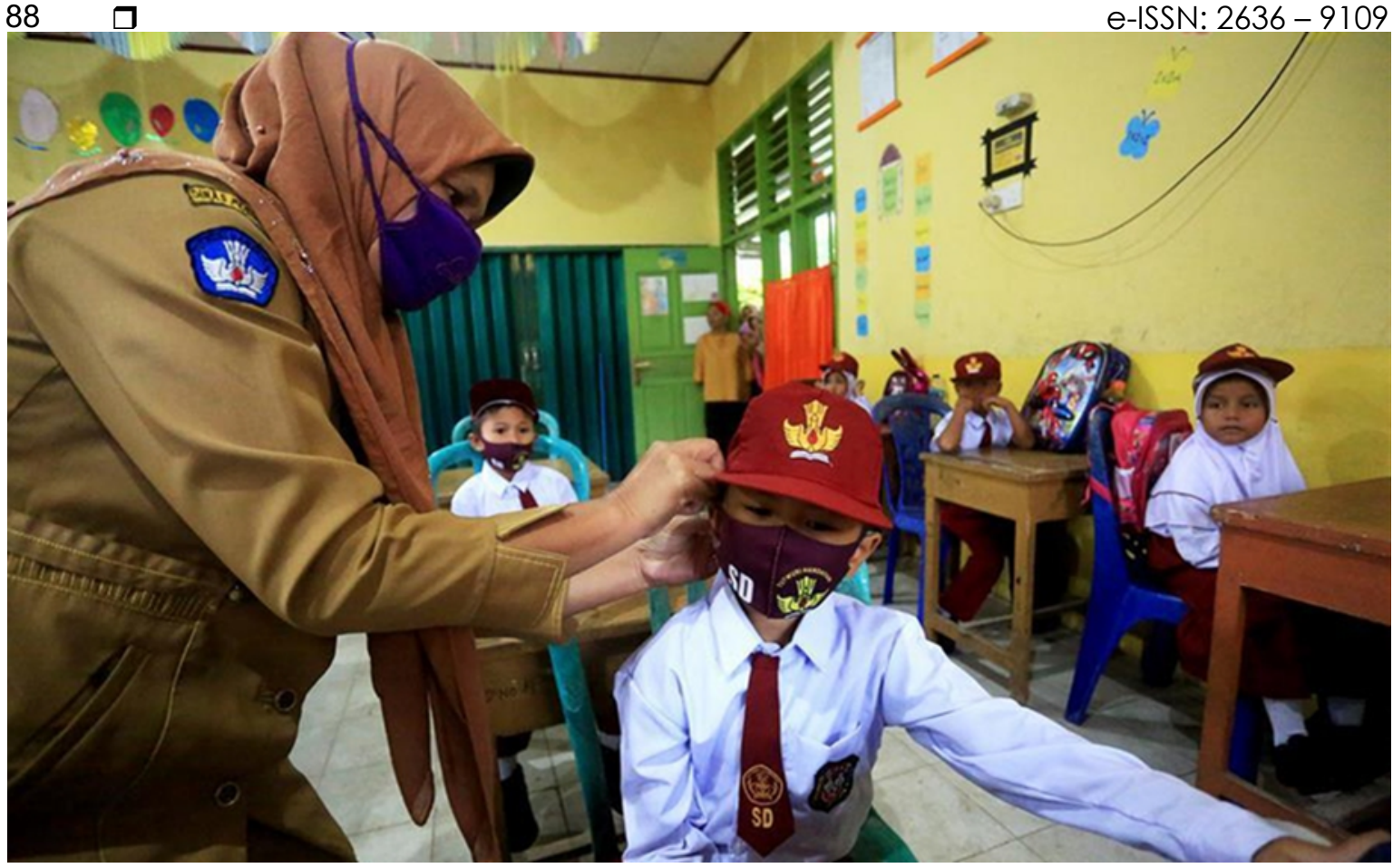

(Source: https://www.globaltimes.cn/content/1194402.shtml)

Those who accept new normal life must be able to maintain health protocols, wherever they are for the sake of human safety in general. There is a sense of offense in the middle of the community if this regulation is applied in their lives. It is inconvenient to interact in the form of social communication with physical and social distancing. Because of that, there is an issue in social interaction because of being suspicious with the other person. This happens because there is excessive suspicion with the person being talked about because it is not in front of the face. But harmonious communication must be built in the midst of the adaptation of the culture of prevention Covid-19 in order to keep creating comfortable social interaction in the community in the form of communication.

As we know, communication interaction is simply a process in which messages are reported from the source, namely the communicator to the recipient or the communicant, both directly and through certain media. In the process of changing social communication, the messages contained and reported by the source to the recipient in the form of ideas for updates or innovations are done through a means of communication using technology such as Instagram, WhattApp, Facebook and other media. All this is done by the government to keep distance or social distancing. Therefore, with the influence of social communication can create social change in people's lives. 


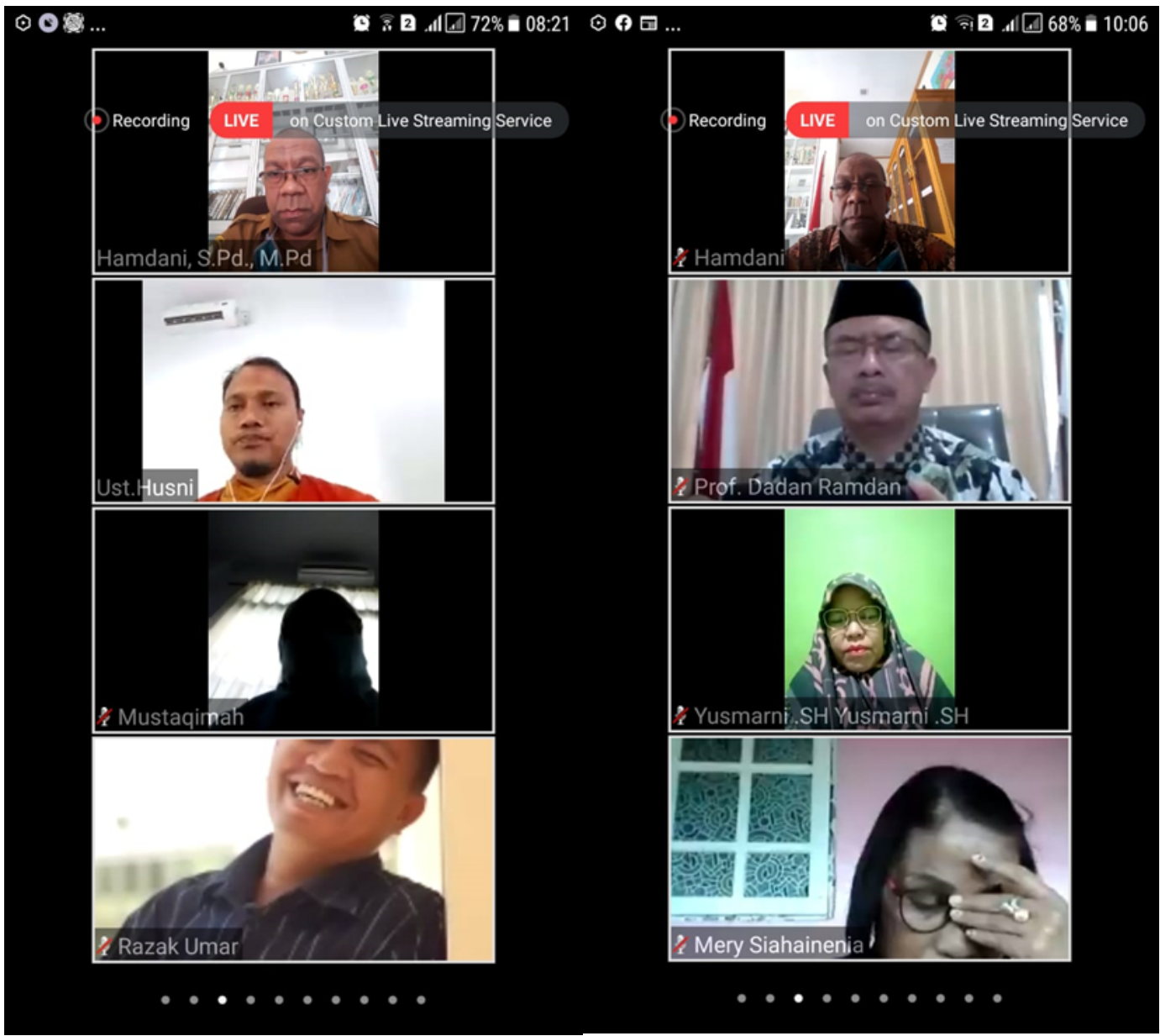

(Source: privat photos library)

Due to the rampant spread of information about Covid-19, it has caused a social change in the community, one of which is the influence in social communication interactions. The community is required to be able and accustomed to using technology in communication. Because these changes often occur in the way they communicate, how they think, and how they behave as social beings. Actually, this change in social communication is caused by the outbreak of the virus in accordance with the development of communication technology through digitalization, which we unconsciously have realized in human life today.

\subsection{Communication as a Social Process}

In the process of social relations, communication becomes a system of social change. Communication plays a role in bridging differences in society because it is able to re-glue the social system of the community in its efforts to make changes. However, communication will also not be separated from its social context.

This means that it will be colored by the attitudes, behavior, patterns, norms, institutions of the people. So both influence and complement each other social interactions, as does the relationship between humans and society. Little John (1999) explains this in the genre of interactionist theories. In this theory, it is explained that understanding social life as a process of interaction

Communication interaction is a means by which humans learn to behave. Communication is the glue of society in social form. Society cannot exist without communication. Social structures - social structures are created and sustained through the interaction of a communication. The language used in communication is to create various social structures in people's lives.

Communication as a social process is an integral part of people's lives. Broadly speaking, communication as a social process in society has the following functions: (a) Communication can connect between various components of society. The components here are not only individuals and communities, but also various forms of social institutions; (b) Communication can open up a new human civilization; (c) Communication is a manifestation of social control in the social fabric of society, (d) Communication plays a role in the socialization of behavioral values to the community; and (e) A person will be identified as a human being by 
using communication. It also means that communication shows a person's social identity in interacting socially that cannot be influenced by various social lives.

\subsection{The influence of social communication on cultural processes in the midst of the Covid-19 outbreak}

The relationship of communication with cultural processes aimed at other people or groups is a cultural exchange so that the impact on communication influences social life. The process of social communication contains cultural elements, one of which is language. Language is a means for the occurrence of a communication in the cultural life of society. Therefore, the influence of social communication is also referred to as a cultural process. Koentjaraningrat (in Nurudin, 2004) states that culture is the whole ideas and works of humans. They must familiarize themselves with learning, along with the whole of the results of their mind and work. From this definition, it is necessary to understand that in culture there are human ideas and works. It means that human ideas and works will become a culture after they have been familiarized with the learning system. Therefore, looking at culture only in terms of the results of human work is not right. Likewise, seeing things only from human ideas is too narrow.

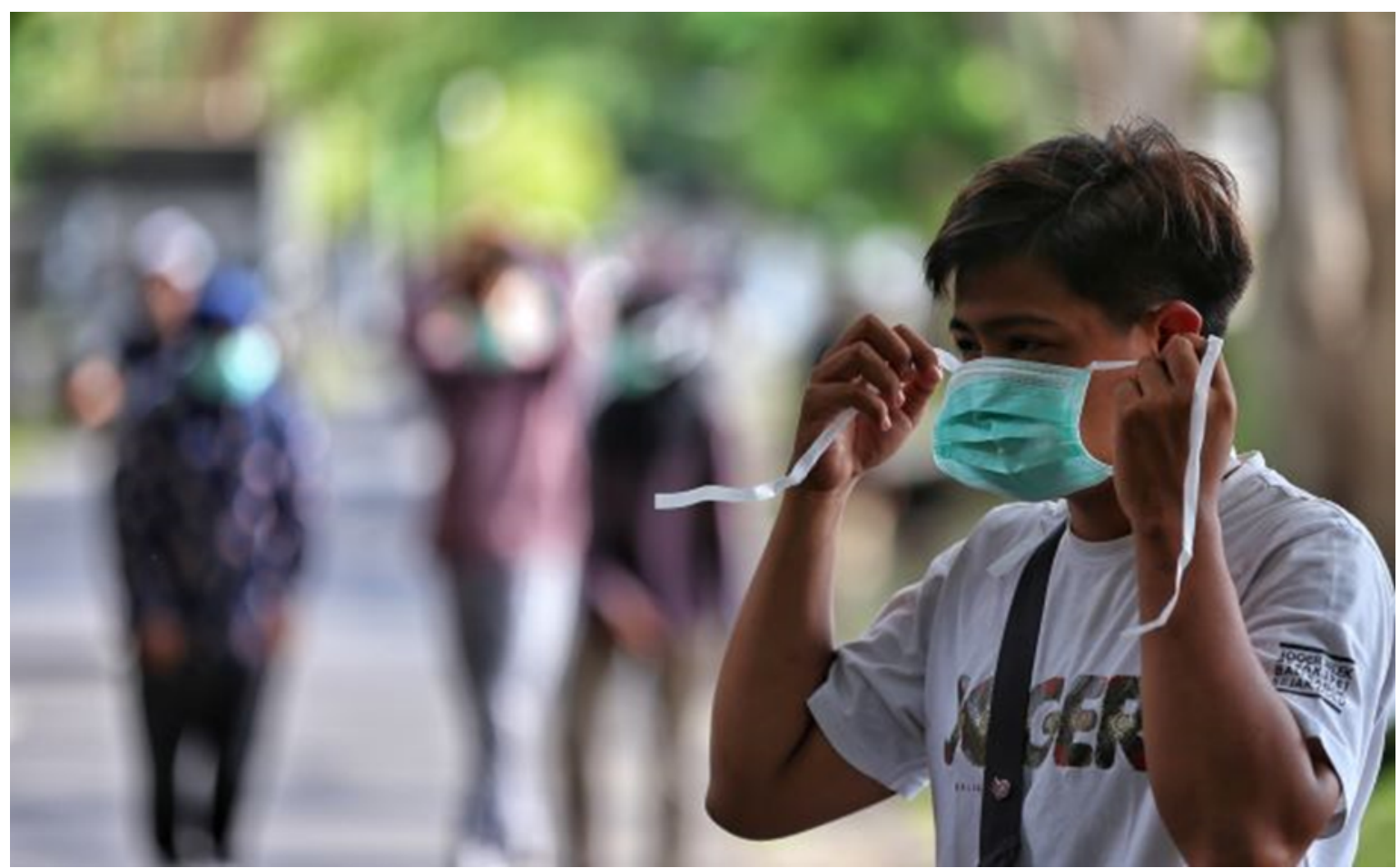

(Source: https://lombokpost.jawapos.com/opini/15/07/2020/perubahan-sosial-di-era-pandemi/)

If it is understood correctly, culture can find its form when viewed as a whole through means of communication, especially with the Covid-19 outbreak. The influence of social communication has been shown by a change in people's lives. The activities of gathering together, recitation, social gathering, routine which is usually done in several places, has begun to be reduced as a form of social distancing which became one of the solutions to prevent the spread of Covid-19. In general, changes that occur in the culture of society can be seen in three aspects namely; (1) the aspect of ideas. It is a construction of thought that is built socially in the community as the culture bearer in addressing the environment and circumstances, including the conditions of this pandemic. The strong idea of the community is that they are not able to feed their family if they do not work is one of the factors that reinforce them to keep working and do not heed the government's call to stay at home; (2) the aspect of values. It is the idea of a measure of whether an experience or action can mean appropriate or inappropriate in the community. For example, the value of trust is partly subject to changes due to public policy in the midst of a pandemic. People who used to do ta'ziyah, tahlilan, slametan for marriage, and so on are now beginning to be restricted or urged to keep distance as a form of government policy in overcoming Covid-19; and (3) aspects of norms. They are understood as unwritten rules together in living life also experience many changes due to a pandemic. Small examples such as when meeting other people with the habit of shaking hands, are now being prohibited to practice in the community. With these 
conditions, the community must be able to understand the situation and begin to adapt to the socio-cultural system which shifts a little without eliminating existing values.

A culture is not just a concept because a culture has its own form among others. From this, culture is defined as (a) being a complex of ideas, concepts and human thoughts, (b) being as a complex of activities, and (c) being as an object or tool that can be used to communicate in the form social. It is because communication is one form of culture. It can only be realized after previously there was an idea that would be issued by the human mind itself which is now done online or offline as a social distancing system in accordance with health protocols. In the context of a community, it becomes a group of activities. Finally, the communication that is carried out often results in a physical form like working to build a building. This is a concept which is channeled through means of communication in social form and then discussed with the family, worker or architect to build a house. Then communication obviously becomes a form of culture, so that the influence of social communication will impact on the change of a culture in people's lives. In other words, communication can be called a cultural process that exists in society.

In the practice of social communication, humans have the tools needed as a means of communication interaction in their lives in accordance with the culture of an area in the application of communication as humans. Equipment needed such as human organs in moving a communication both verbal and written. Viewed more broadly with the spread of communication in social life during Covid-19, it is believed that this pandemic can affect a culture in communication interactions. Human communication can do a variety of interactions, including generating livelihoods so as to turn on the family economy. When social communication is disrupted continuously it will also impact on human life both culturally and economically.

\section{Conclusion}

Communication happens in social interaction is unlimited and restricted by values of etiquette. Generally, the pattern of social communication can influence people's interaction during the Covid-19 pandemic. It is due to the reason that communication is a standard benchmark to be applied so that people could carry on their activity during the pandemic. The influence of communication on social culture depends on the government who has power to assert the influence. Because of this, the influence of social communication due to social distancing stated in the guideline for the quick handling of medical and public health in Indonesia, the spread of Covid-19 becomes a serious threat worldwide. The increasing number of infected people leads to the fact that people should practice social distancing in a way to minimize their social interaction during the pandemic. Such restricted in communication could influence social culture especially on how people do their routines or activities.

Communication that occurs in the interaction of kinship relationships is very broad and builds ethical values of decency. In general, social communication patterns can affect community interactions during Covid-19 because communication is the middle measure of how it is implemented during Covid - 19 to be able to carry out their respective activities. The power of the character to maintain its influence on social culture so that it can be said that the influence of social communication, due to distance or social rise, in the Guidelines for Medical and Public Health Handling of COVID-19 in Indonesia, the Spread Virus is a serious threat to the world. The busier patients affected by the corona virus are, this social distance directs the public to their social interactions in dealing with the Covid-19 pandemic which is limited by communication through communication which can affect the culture of the community in their daily activities.

Reducing social interaction through social distancing is aimed at preventing the wider spread of corona virus. It is done by minimizing the use of public facilities and maintaining social interaction. People are enforced to stay at home while doing their routines and maintain their communication with the others.

Communication, as we know, plays a role in bridging differences in society. It is able to re-glue the social system of the community in its efforts to make changes. In other words, communication as a social process is an integral part in society. It cannot be separated from the context of society that functions to connect various components of society, to open up a new human civilization, to play a role in the socialization of behavioral values to the community, and to be identified as a human being by practicing communication.

The relationship of communication with cultural processes is a cultural exchange so that the impact on communication influences social life. One of cultural elements that involve in this is a language. Therefore, culture contains human ideas and works. The influence of social communication during the Covid-19 pandemic has been shown by the change in people's live. Activities such as social gathering have been affected by a form of social distancing. These changes can be seen from the aspect of ideas, values and norms. 
Based on the explanation above, the writer suggests recommendation that the influence of communication should be viewed from two perspectives; first, communication is useful for social life; yet, people need to be careful in their social interaction by looking at the wide spread of Covid-19. As we know, society not only needs to be protected from the outbreak of the Covid-19, but their welfare also needs to be fulfilled.

Social interaction and physical distancing can be a solution to halt the spread of the virus. However, society's roles in influencing communication cannot be taken for granted. There is a need to do more research on how cultural elements play a part in social communication because the current pandemic can change people's lives by influencing their social communication. Moreover, it is important to research in a detail on how technological advances influence the social life of society. Even though technology has benefits on human's life, minimizing some negative effects should also be considered further.

\section{References}

Abd. Syukur Ibrahim, 1994. Panduan Etnografi Komunikasi, Usaha Nasional, Surabaya, Andrik purwasito, Komunikasi Multikultural, UMS: Muhammadiyah University press. Clifford Geertz, 1992.

Arifin, Anwar.1998. Ilmu Komunikasi. Jakarta: Raja Grafindo

Bungin Burhan.2006. Sosiologi Komunikasi. Jakarta: Kencana PMG

Communication in Context.New York: Mc Graw Hill International

De Vito A. Yoseph, Communology: An Introduction to the Study of Communication, Herper \& Row Publishers, New York, 1978

Deddy Mulyana, Komunikasi Efektif Suatu Pendekatan Lintas Budaya, PT Remaja Rosdakarya, Bandung, 2004

Edy Sudaryanto, Relevansi, Fungsi, dan Peranan Komunikasi Dalam Pembangunan, PPs, UNPAD, Bandung, 1997

Erwin R.Mcdaniel, Larry A. Samavor, Ricard. 2007. Komunikasi Lintas Budaya: Jakarta: Selemba Humanika

González-Padilla, Daniel A; Tortolero-Blanco, Leonardo. Social media influence in the COVID-19 Pandemic. Int Braz J Urol; 46(suppl.1): 120-124, 202007.

Hartati, Lavinia Yuni. 2012.Peran Komunikasi Antarbudaya Dalam Mengatasi Miskomunikasi Antar Mahasiswa. Jurnal Reformanis. Vol. 1 No. 1

Hedi. 2013. Komunikasi Antar Budaya Dalam Masyarakat Multikultural. Jurnal Kajian Komunikasi. Vol 1 No. 1

https://www.WhatsApp.com/features/. (Online: Diakses tgl. 15 Oktober 2017)

Hussain, Wajahat. (2020). Role of Social Media in COVID-19 Pandemic. The International Journal of Frontier Sciences. 4. 10.37978/tijfs.v4i2.144.

Lihapsari Prihatini dkk., Teknik Komunikasi Tepat Guna Dalam Mengatasi Segala Bentuk Perubahan, Bandung: PPs UNPAD, Bandung, 1997.

Liliweri, Alo. 2007. Dasar Dasar Komunikasi Antarbudaya. Yogyakarta: Pustaka Pelajar

Liliweri, Alo. 2007. Makna Budaya Dalam Komunikasi Antarbudaya. Yogyakarta: Pelangi Aksara

Majid, Abdul. 2014. Pasar Sebagai Sarana Komunikasi Antar Budaya. Jurnal Ilmu Komunikasi. Vol. 2 No. 1

Mulyana, Deddy. 2000. Human Communication, Konteks-Konteks Komunikasi. Bandung: Remaja Rosdakarya.

Palfrey, John dan Gasser, Urs. 2008. Born Digital Understanding The First Generation of Digital Natives. New York: Basic Book.

Publications. Martin, Judith dan Thomas K. Nakayama. 2007. Intercultural

Straubhaar, Joseph, dan Robert LaRose. 2006. Media Now: Communications Media in The Information Age, Belmont USA: Wadsworth/Thomson Learning.

Tapscott, Don. 2009. Grown Up Digital: How the Net Generation Changing Your World. iMc Graw Hill. 
Tasnim, Samia \& Hossain, Md Mahbub \& Mazumder, Hoimonty, 2020. "Impact of rumors or misinformation on coronavirus disease (COVID-19) in social media," SocArXiv uf3zn, Center for Open Science, [2020-07-29]. https://ideas.repec.org/p/osf/socarx/uf3zn.html

World Health Organization Coronavirus. 2020. [2020-07-29]. https://www.who.int/healthtopics/coronavirus\#tab=tab_2. 